\begin{tabular}{ll}
\hline TOBA (Journal of Tourism, Hospitality and Destination) \\
journal.literasisains.id/index.php/TOBA \\
ISSN Media Elektronik 2828-4100 \\
Vol. 1 No. 1 (Februari 2022) 25-29 \\
DOI: https://doi.org/10.55123/toba.v1i1.107
\end{tabular}

\title{
Strategi Pengembangan Kampung Wisata Berbasis Kearifan Lokal di Desa Mirat Kabupaten Majalengka
}

Fitri Fadhilah Sumiarsa $^{1}$, Kiky Yustikasari ${ }^{2}$, Evi Novianti $^{3}$

Magister Pariwisata Berkelanjutan, Sekolah Pascasarjanan Universitas Padjajaran email: fitri14013@unpad.mail.ac.id,

\begin{abstract}
ABSTRAK
Desa Mirat merupakan sebuah desa di kecamatan Leuwimunding, Kabupaten Majalengkan jawa Barat. Desa ini merupakan salah satu desa yang memiliki potensi untuk menjadi desa wisata. Penelitian ini bertujuan untuk mendeskripsikan strategi pengembangan kampung wisata di Desa Mirat Kabupaten Majalengka berbasis budaya lokal. Untuk menjawab tujuan tersebut dilakukan pengumpulan data melalui pengamatan (observasi) dan literature review dari berbagai jurnal, kemudian data yang diperoleh dianalisis secara deskriptif kualitatif. Data dianalisis ke dalam lima kriteria desa wisata yang meliputi daya tarik, aksesibilitas, fasilitas umum fasilitas wisata, pemberdayaan masyarakat, dan pemasaran atau promosi. Hasil penelitian menunjukan bahwa dalam pembangunan desa wisata yang mengacu pada ke lima kriteria desa wisata, Desa Mirat hanya memenuhi dua kriteria secara maksimal yakni daya tarik wisata dan pemberdayaan masyarakat, sedangkan ketiga kriteria lainnya masih menemui kendala.
\end{abstract}

Kata kunci : Desa Wisata; Kearifan Lokal; Pengembangan Wisata,

\section{ABSTRACT}

Mirat Village is a village in Leuwimunding District, Majalengka Regency, West Java. It is one of the villages with the potential to become a tourist destination. Using local culture as a foundation, this study aims to describe the development strategy of a tourist village in Mirat Village, Majalengka Regency. To achieve these objectives, data collection is conducted through observation and a literature review of various journals, and the resulting data is analyzed descriptively and qualitatively. Upon data analysis, five categories were identified, including attraction, accessibility, public facilities, community empowerment, and marketing or promotion. The results of the research revealed that Mirat Village only meets two of the five tourist village criteria, namely tourist attraction and community empowerment, while the other three criteria are still hindered.

Keywords : Local Wisdom; tourism development; tourist village.

\section{A. PENDAhuluan}

Pariwisata termasuk diantara sektor pendapatan berkembang pesat dan memiliki potensi besar. Dalam pengembangannya, industri pariwisata memiliki peluang untuk meningkatkan perekonomian masyarakat daerah. Berbagai upaya pun dilakukan dalam mengembangkan potensi pariwisata di sebuah destinasi. Salah satunya adalah dengan mengembangkan pariwisata di desa-desa.

Indonesia sendiri merupakan negara dengan kebudayaan yang sangat beragam. Baik dari adat istiadat, kekayaan alam, hingga ragam karakteristik lokal yang tersebar di seluruh desa di Indonesia. Dari keanekaragaman budaya dan nilai tradisional budaya tersebut suatu desa adat memiliki daya tarik tersendiri. Daya tarik inilah yang menjadi peluang untuk berkembangnya industri pariwisata dengan budaya sebagai objeknya.

Daya tarik unsur-unsur budaya sebagai basis pengembangan wisata di era global ini dapat didasarkan pada alasan dari perspektif strategi budaya yakni meningkatnya pengaruh globalisasi telah menjadi penurunan nilai budaya bangsa. Budaya lokal memiliki potensi dan peran budaya tandingan (counter culture) bagi dominasi budaya global yang dianggap sebagai sesuatu yang tak terelakkan). Budaya lokal dinilai baik jika ia bisa menjadi sumber kearifan lokal, juga sikap kritis terhadap globalisasi.
Meski terjadinya globalisasi dan modernitas, juga dunia luar yang bersifat homogen, ketergantungan masyarakat terhadap nilai-nilai luhur seperti sastra, seni dan agama harus semakin kokoh. (Farhan \& Anwar, 2016)

Badan Pusat Statistik (2018) mencatat Indonesia memiliki 83.931 desa dimana di antaranya terdapat 1.734 desa wisata. Angka tersebut tentu bisa lebih banyak apabila setiap desa memaksimalkan potensi yang ada di dalamnya, baik itu kebudayaan, tradisi, bahkan kuliner khas yang ada di desa tersebut. Namun dalam mengembangkan desa wisata, tentu harus ada penerapan pembangunan pariwisata berkelanjutan. Dalam pemaparan bukunya, Sunaryo (2013) menguraikan kinerja pembangunan kepariwisataan dari beberapa indikator, diantaranya adalah aspek indikator lingkungan fisik dan aspek indikator sosial budaya. Dalam lingkungan fisik sendiri diperlukan adanya pengukuran secara periodik dari sumber daya alam atau ekologi bukan buatan manusia, misalnya lanskap, hutan, danau, air tanah, udara, flora dan fauna.

Kawasan Desa Mirat Kabupaten Majalengka Jawa Barat memiliki sangat berpotensi menjadi Des wisata pedesaan. Desa ini memiliki karakteristik alam yang menarik, kehidupan masyarakat unik, juga sosial dan budayanya. Mengembangkan wisata desa dianggap penting karena desa wisata memberi banyak 
keuntungan bagi masyarakat yang tinggal di sekitar desa tersebut. Pengembangan desa wisata juga termasuk dalam investasi jangka panjang untuk masyarakat dan pemerintah daerah. Desa Mirat dinilai menjadi contoh yang baik karena desa ini sudah memiliki sumber daya manusia dan sumberdaya alam untuk menarik wisatawan. Penelitian ini dilakukan bertujuan untuk mengetahui seberapa jauh pengembangan desa wisata ini dilakukan masyarakat juga strategi apa saja yang bisa dilakukan guna mengembangkan potensi desa wisata di desa Mirat. Pengembangan desa wisata dapat mengikutsertakan partisipasi masyarakat. Kuncinya adalah bagaimana mendorong masyarakat untuk sama-sama membantu mengembangkan pariwisata.Dengan partisipasi yang baik niscaya ini akan menghasilkan hasil yang baik juga bagi desa wisata.

Maka diperlukan hubungan dan kerja sama yang sinergis antara masyarakat, pemerintah daerah juga para stakeholder untuk mencapai tujuan desa wisata yang diinginkan. Upaya dari pemerintah daerah di Indonesia memliki alas an yang kuat. Pariwisata dinilai berpotensi besar untuk menjadi salah satu pilar dalam pembangunan ekonomi nasional. (Lubis \& Osman, 2014)

Kabupaten Majalengka adalah salah satu kabupaten di Provinsi Jawa Barat. Secara geografis Kabupaten ini terletak di bagian timur Provinsi Jawa Barat. Kabupaten Majalengka terletak pada titik koordinat yaitu Sebelah Barat $108^{\circ} 03^{\prime}-108^{\circ} 19$ BT, Sebelah Timur $108^{\circ} 12^{\prime}-108^{\circ} 25$ BT, Sebelah Utara $6^{\circ} 36^{\prime}-5^{\circ} 58$ LS dan Sebelah Selatan $6^{\circ} 43^{\prime}-7^{\circ} 44$. Dalam sektor pariwisata kabupaten ini dinilai cukup berkembang. Khususnya dengan adanya Bandara Kertajati. Pemerintah daerah majalengka harus semakin giat mengembangkan potensi wisata ini. Seperti daerah Jawa Barat lainnya, Kabupaten Majalengka bergantung pada wisata alamnya beberapa DTW alam di daerah Majalengka diantaranya: perkebunan the Cipasung, Panorama Cikebo, Bendungan rentang dan Wana Wisata Gunung Panten. Adapun wisata sejarah Budaya di Kabupaten Majalengka seperti Museum Talaga Manggung dan Rumah Adat Panjalin. Untuk penelitian ini, penulis berfokus pada salah satu desa di kecamatan Leuwimunding, yaitu desa Mirat. Terdapat beberapa DTW alam di kawasan desa ini dan dianggap memiliki potensi besar untuk menjadi desa wisata.

\section{B. KAJIAN LITERATUR}

Kearifan lokal dalam Pengembangan Desa Wisata Dalam pembangunan kepariwisataan ada istilah yang disebut dengan strategi perencanaan pengembangan pariwisata yang berhubungan dengan pemberdayaan masyrakat yang bertumpu pada kontribusi masyarakat yang arif dan bijaksana dalam mengembangkan pariwisata. Strategi pengambangan ini disebut Kearifan Sosial atau Community-Based
Toursim Development (CBT). Partisipasi masyarakat dalam pengembangan atau proses perencanaan sangat dianjurkan sebagai salah satu cara menerpakan pariwisata berkelanjutan.(Okazaki, 2008) Konstribusi masyarakat yang dimaksud tidak hanya bertujuan untuk mencapai keberlanjutan sumber daya material yang efisien tetapi kontribusi juga termasuk di dalamnya berbagi pengetahuan dan proses perubahan. (Connell, 1997) Prinsip CBT ini termasuk konsep yang krusial dalm pengembangan wisata. Sunaryo (2013) mengemukakan bahwa pada dasarnya, konstruksi CBT merupakan suatu prinsip atau gagasan yang signifikan dalam perkembangan wisata modern yang menojonjolkan keunikan komunitas lokal. Komunitas lokal menyumbangkan waktu dan tenaga sebagai bentuk investasi pada pengembangan wisata. (Goodwin \& Santilli, 2009). Pada hakikatnya pembangunan pariwisata tidak terlepas dari faktor alam dan non alam (tradisional atau budaya) bentuk dan sumber daya serta keunikan masyarakat setempat, hal ini merupakan faktor pendorong utama dalam kegiatan pariwisata, oleh karena itu pariwisata harus dipandang bertumpu pada Kegiatan masyarakat setempat biasanya disebut sesuai dengan kearifan lokal masyarakat setempat.

Kearifan lokal dapat didefinisikan sebagai gagasan hidup. Ide yang didasarkan pada pikiran yang jernih, karakter mulia dan mengandung kepositifan. Kearifan lokal dapat dieksplorasi dengan menelusuri proses pembelajaran dari satu generasi ke generasi berikutnya (Mungmachon, 2012). Salah satu kendala yang dihadapi oleh setiap destinasi wisata adalah sulitnya menjaga keaslian alam dan keunikan kehidupan sosial budaya dan tradisi. (Diana \& Setiawan, 2021) Alasan utamanya adalah dengan berkembangnya pariwisata, struktur sosial masyarakat telah berubah, dan produk-produk eksternal juga berubah atau meningkat. Di banyak kasus, produk wisata yang baru ini menghilangkan nilai-nilai luhur masyarakat yang seharusnya tidak boleh diganggu dan harus dilestarikan. Maka dari itu CBT seharusnya bukan sekedar bisnis pariwisata yang bertujuan menjcari keuntungan setinggi-tingginya melainkan harus dinilai dari seberapa besar efek yang didapat oleh masyarakat setempat. (Suansri, 2003). Produk wisata terbilang rentan lantaran beberapa aspek dalam produk wisata seperti keindahan alam, kehidupan sosial, kekayaan spiritual merupakan daya tarik yang menarik perhatian wisatawan untuk datang ke suatu DTW. Partisipasi masyarakat dalam kelompok ini merupakan salah satu bentuk aksi masyarakat yang peduli terhadap kawasan wisata dan potensi sumber daya alam lainnya. Jika masyarakat bisa hidup berdampingan secara harmonis maka wujud kearifan lokalnya bisa terwujud.

\section{METODE PENELITIAN}

Metode yang penulis gunakan untuk penelitian ini adalah metode kualitatif dengan pendekatan studi kasus. Creswell (2010) mendefinisikan studi kasus 
strategi pemilihan di mana di dalamnya peneliti menyelidiki secara cermat suatu aktivitas dan peristiwa dari sekelompok individu. Peneliti mengumpulkan data dari berbagai sumber pustaka dan hasil observasi lapangan. Pemaparan hasil penelitian disampaikan secara deskriptif berdasarkan data kualitatif. Menurut Ary (2010), penelitian kualitatif menghasilkan data-data yang berupa katakata atau gambar bukan angka dan statistik. Analisi dan pembahasan dalam penelitian didasarkan oleh lima kriteria serta konsep desa wisata.

Pemilihan metode ini dilakukan berdasarkan atas pertimbangan bahwa data ini bisa dipahami sebagai suatu kesatuan dan dapat menjaga keutuhan objek penelitian.

\section{HASIL DAN PEMBAHASAN Daya Tarik Desa Mirat}

Desa Mirat merupakan desa yang berada di Kecamatan Leuwimunding, Kabupaten Majalengka, Provinsi Jawa Barat dengan luas wilayah 2,908 km2 atau $0,174 \%$ dari luas wilayah daratan Kabupaten Majalengka, dengan koordinat 108.35002BT/67.33419LS. Desa Mirat berjarak kurang libih 195 Km dari Pusat Kota Bandung dengan jarak tempuh \pm 3 Jam. Desa Desa Mirat memiliki dua potensi wisata andalan yang dapat dikembangkan diantaranya, atraksi wisata alam atau natural attraction dan cultural attraction. Atraksi wisata alam atau natural attraction yang berpotensi menjadi DTW diantaranya adalah Cadas Gantung, Mata Air Cilarangan, Tebing Cirarangan dan Mata Air Cibalong. Atraksi wisata ini cukup berpotensi untuk dikembangkan. Dengan bantuan pemerintah daerah juga bantuan masyarakat desa, Atraksi wisata ini bisa menarik lebih wisatawan dari luar desa.

Selain itu, Desa Mirat juga memiliki potensi cultural attraction atau wisata budaya yang dapat dikembangkan yaitu seperti wisata ziarah ke makam ke sesepuh di desa mirat. Kecenderungan melakukan perjalanan ziarah dapat dikembangkan dan diberi perhatian khusus sebagai wisata

budaya. Wisata ziarah diantaranya Petilasan Arya Kemuning, dan Petilasan Mbah Kuwu Sangkan di dekat Gua Pangisan diatas tebing Jamparing. Selain itu ada keunikan lain di Desa Mirat yaitu pemakaman yang dipercayai sebagai makam keramat yaitu terletak di Dusun Mekar Saluyu RT 004 RW 004, Desa Mirat Kecamatan Leuwimunding Kabupaten Majalengka Jawa Barat dan merupakan pemakaman tertua. Potensi atraksi ini sangat menarik dan kental akan budaya dan ciri khas suatu daerah. Dengan pengelolaan yang baik wisata ini dapat menjadi trademark dan daya tarik wisata Desa Mirat. Wisata yang penuh akan sejarah cukup diminati oleh masyarakat Indonesia.

\section{Aksesibilitas}

Peraturan Pemerintah No. $50 \quad$ (2011) menyebutkan bahwa aksesibilitas mengacu pada kemudahan berpindah dari satu tempat ke tempat lainnya. Dalam kegiatan wisata, pembangunang dapat terwujud dengan kemajuan teknologi modern, diantaranya teknologi transportasi dan komunikasi. Transportasi semacam ini dibutuhkan untuk mengantarkan wisatawan dari tempat asalnya atau tempat tinggal menuju tempat tujuan wisata. Namun pengguna moda transportasi ini sangat bergantung pada jarak dan kebutuhan komunikasi ke titik awal obyek wisata yang akan dikunjungi. Kendala menuju Majaalengka adalah akses ke tempat wisata yang masih sulit dijangkau, bahkan beberapa jalan raya yang sulit diakses oleh kendaraan bermotor.

Yoeti (1996) menganggap aksesibilitas sebagai aspek yang penting bagi suatu destinasi wisata. Jika suatu destinasi tidak memiliki aksesibilitas yang layak dan memadiai maka tempaat itupun akan sulit berkembang menjadi destinasi wisata.

Aksesibilitas menuju desa wisata Mirat dinilai masih kurang memadai. Untuk menuju ke destinasi para wisatawan membutuhkan waktu tempuh sekitar 3 jam dari pusat kota Bandung. Saat ini akses menuju desa mirat hanya bisa dilalui oleh kendaraan pribadi, belum tersedia kendaraan umum resmi yang melintas. Selanjutnya untuk melanjutkan perjalanan menuju daya tarik wisatanya membutuhkan tenaga lebih. Selain itu beberapa DTW hanya dapat dilalui oleh kendaraan roda dua dengan kondisi jalan yang cukup memprihatinkan. Jika wisatawan tidak membawa kendaraan roda dua, masyarakat sekitar menawarkan wisata antar jemput menuju DTW. Dengan kondisi aksesibilitas yang kurang, diharapkan pihak pemerintah daerah ataupun pengelola mengambil andil untuk pembangunan infrastruktur dalam desa Mirat.

\section{Pemberdayaan Masyarakat}

Kondisi pariwisata di desa mirat masih dinilai belum maksimal dikarenakan pengelolaan desa mirat masih berada di tahap awal pembangunan kepariwisataan menuju desa wisata, sejauh ini pemerintah Desa Mirat sudah banyak melibatkan masyarakat setempat untuk berkontribusi. pengembangan pariwisata yang baik harus banyak melibatkan masyarakat secara langsung. Masyarakat setempat harus memperoleh manfaat sebesarbesarnya dari pengembangan wisata ini bukan sebaliknya.(Dalimunthe, 2007) Salah satu cara melibatkan masyarakat dalam pembangunan wisata, pemerintah setempat mengadakan beberapa audiensi untuk berbagai lapisan masyarakat di desa Mirat. Seluruh lapisan masyarakat seperti lulusan sarjana, pendidik, pegiat seni, wiraswasta, juga komunitas pemuda ikut serta dalam diskusi.

Dalam audiensi, masyarakat desa biasanya mendiskusikan perihal pengelolaan desa khususnya finansial. Mereka memastikan bahwa seluruh 
kebijakan pemerintah desa menguntungkan seluruh lapisan masyarakat. Menurut catatan desa, pendapatan terbesar yang masyarakat dapat datang dari sektor pertanian dan perkebunan. Diskusi ini membicarakan beberapa hal yang berkaitan dengan pengelolaan finansial Desa Mirat. Masyarakat menginginkan seluruh pendapatan asli desa terasa hingga ke semua lapisan masyarakat.

Salah satu bentuk pemberdayaan masyarakat desa adalah mengadakan sosialisasi secara berkala untuk membangun awareness mengenai potensi wisata dan bagaimana mengelolanya. Masyarakat perlu motivasi untuk bisa mengambil andil dalam pengelolaan desa wisata. Jika wisata desa Mirat sudah mulai terkelola dengan baik maka tahap selanjutnya sektor ekonomi dan usaha desa akan ikut maju. Pemberdayaan Masyarakat dalam mengelola desa wisata sangat penting dilakukan dibandingkan memberi kuasa penuh terhadap pihak investor, Masyarakat asli desa akan menjaga kelestarian budaya desa Mirat ini sekaligus mempromosikan budaya dan produk lokal.

\section{Fasilitas Umum dan Fasilitas Wisata}

Fasilitas meliputi seluruh jenis sarana yang khusus dibangun dengan tujuan mendukung atau mempermudah kenyamanan dan keselamatan wisatawan pada saat berkunjung ke destinasi tersebut.(Komariah dkk., 2018) Selain memberikan kenyamanan pengunjung, fasilitas di destinasi wisata juga memungkinkan para wisatawan untuk berinteraksi dan mengenal warga sekitar mengenai buda dan kearifan lokal.

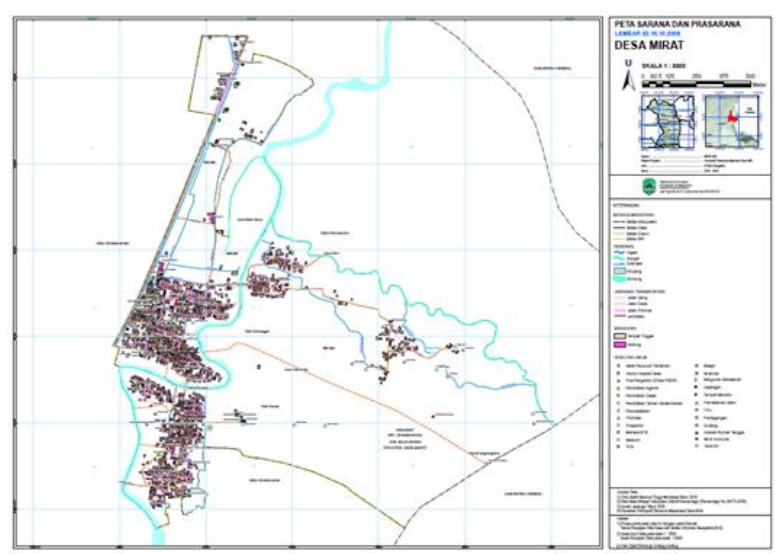
Mirat

Gambar 1. Peta sarana dan prasarana Desa

Gambar 1. merupakan peta citra dan peta sarana prasarana yang ada di desa Mirat. Selain atraksi wisata yang tersedia, ada pula sarana penunjang seperti masjid, mushola, bangunan bersejarah, Pemakaman islam, Industri rumah tangga dan sarana pendukung lainnya.

\section{Pemasaran dan Promosi}

Pemasaran dan promosi merupakan hal yang krusial bagi sektor wisata. Jika suatu DTW telah mengalami pengelolaan yang baik maka langkah selanjutnya adalah pemasaran dan promosi yang layak. Kegiatan Pemasaran dan promosi merupakan hal intenstif untuk untuk memperkuat daya tarik produk wisata kepada calon wisata. Ada berbagai cara yang bisa dilakukan oleh pengelola wisata untuk menaikan pemasaran dan promosi suatu DTW. Beberapa contoh bentuk promosi yang bisa dilakukan pengelola, pertama, melakukan kerjasama dengan intansi terkait seperti tour \& travel. Kedua, memakai jasa iklan di beberapa media seperti media cetak, radio atau televise. Atau yang terakhir dan cara termudah adalah memanfaatkan internet dengan cara mempromosikannya lewat website atau media social. Untuk saat ini aktivitas promosi untuk Destinasi Desa Mirat masih belum terstuktur dan terencana secara baik.bila calon wisatawan mencari informasi perihal desa mirat, tidak banyak informasi wisata yang muncul. Sejauh ini promosi hanya dilakukan lewat pesan orang ke orang. Hal ini terjadi karena sektor wisata belum menjadi fokus program kerja.

\section{E. SIMPULAN}

Nilai kearifan lokal merupakan landasan pembangunan berkelanjutan di desa wisata. Nilai kearifan lokal dalam pengembangan desa wisata di Kabupaten Majalengka dilihat berdasarkan standar desa wisata yang terdiri dari daya tarik wisata, aksesibilitas, fasilitas umum dan fasilitas wisata, pemberdayaan masyarakat dan pemasaran atau promosi. Dari lima standar desa wisata di desa Mirat Majalengka, hanya dua yang memenuhi kriteria, salah satunya atraksi dan pemberdayaan masyarakat. Kita bisa melihat potensi yang menarik dan mengembangkan potensi untuk menarik wisatawan, dan perkembangan masyarakat sudah mulai memberikan kontribusi bagi pembangunan pedesaan dengan antusias masyarakat yang terlihat jelas. Pada saat yang sama, tiga kriteria lainnya masih menghadapi kendala. Hambatan terbesar penerapan ketiga standar tersebut adalah kurangnya sumber daya manusia dan sumber daya anggaran.

\section{DAFTAR PUSTAKA}

Ary, D., Jacobs, L. C., Razavieh, A., \& Ary, D. (2010). Introduction to Research in Education. 8th. Edition. USA: WARDSWORTH Cengage Learning.

Connell, D. (1997). Participatory Development. Development in Practice, 7(3), 248-259. https://doi.org/10.1080/09614529754486

Creswell, J. W. (2010). Research design pendekatan kualitatif, kuantitatif, dan mixed. Pustaka Pelajar.

Dalimunthe. (2007). Partisipasi Masyarakat dalam Pengembangan Potensi Wisata Bahari Pantai Cermin Kabupaten Serdang Badagai. 
Diana, D., \& Setiawan, A. B. (2021). Evaluasi Penerapan Community Based Tourism (CBT) Efficient: Indonesian Journal of Development Economics, 1044-1065.

Farhan, H., \& Anwar, K. (2016). The Tourism Development Strategy Based on Rural and Local Wisdom. Journal of Sustainable Development, $9(3)$. https://doi.org/10.5539/jsd.v9n3p170

Goodwin, H., \& Santilli, R. (2009). CommunityBased Tourism: a success? Community-Based Tourism: a success? ICRT Occasional Paper, 11.

Komariah, N., Saepudin, E., \& Yusup, P. (2018). Pengembangan Desa Wisata Berbasis Kearifan Lokal. Jurnal Pariwisata Pesona, 3. https://doi.org/10.26905/jpp.v3i2.2340

Lubis, Z., \& Osman, A. (2014). Indonesian tourism sector: A potential sector that has not been optimized. . Australian Journal of Basic and Applied Sciences.
Mungmachon, M. R. (2012). Knowledge and Local Wisdom: Community Treasure. International Journal of Humanities and Social Science, 2(13), 174-181.

Okazaki, E. (2008). A Community-Based Tourism Model: Its Conception and Use. Journal of Sustainable Tourism, 16(5), 511-529. https://doi.org/10.1080/09669580802159594

Suansri, P. (2003). Community Based Tourism Handbook. Rest Project.

Sunaryo, B. (2013). Kebijakan Pembangunan Destinasi Pariwisata (Konsep dan Aplikasinya di Indonesia). Gava Media.Spradley.

Yoeti, O. A. (1996). Perencanaan dan Pengembangan Pariwisata. Pradnya Paramita.

husk: isoterm and kinetic study. Jurnal Litbang Industri, 2(2), 45-53.

Subejo dan Supriyanto, (2005), Kerangka Pemberdayaan Masyarakat Pedesaan Menuju Pembangunan Yang Berkelanjutan. Jurnal Ilmu-Ilmu Pertanian No. 1 Juli (2005). 17-32) 